\title{
Religiosity and Purchase Intention of Purwokerto Halal Mart
}

\author{
Pramono Hari Adi ${ }^{1}$, Feronica Via Christiany ${ }^{2}$ \\ ${ }^{1}$ Lecturer of Faculty of Economics and Bussines, Universitas Jenderal soedirman \\ ${ }^{2}$ Student of Faculty of Economics and Bussines, Universitas Jenderal soedirman
}

\begin{abstract}
The research on which entitle Religiosity and Purchase Intension of Purwokerto Halal Mart was aim to analyze the relationship between religiosity and trust in the purchase intention of halal mart retail in Purwokerto. This research is a survey of Taklim Assembly members of the Great Mosque of Baitussalam, Jenderal Soedirman Mosque, Wijayakusuma Mosque, Darussalam Mosque, Bhayangkara Mosque and Fatimatuzahra Mosque. The number of sample were 225 with simple random sampling technique. The statistical test performed is using SEM data analysis. The results show that several dimensions of religiosity, namely experiential, ritualistic, intellectual have positive influence on trust. While the ideological and consequential dimensions do not have a positive effect on trust. For the influence of the dimensions of religiosity on purchase intention namely the experiential, ritualistic, ideological and consequential dimensions have a positive effect on purchase intention, but the intellectual dimension does not have a positive effect on purchase intention. And trust also has a positive effect on purchase intention. This result could inform halal mart and consumers that religiosity empirically influences consumers' trust and purchase intentions, and also consumers' trust influence purchase intention in the halal mart.
\end{abstract}

\section{Background}

Many consumers are starting to take notice of products labeled as halal today. As Muslims majority, not only food products that got attention but also all products that are used in fulfilling everyday needs, such as cosmetics, bath soap, laundry soap, toothpaste, medicine and many others. This phenomenon is interesting among Muslim businessmen to develop Halal Mart which has an advantage of all of the products are guaranteed halal. These halalguaranteed products are expected to be in demand by Muslim consumers. As the servants of Allah, Muslim have an obligation to use halal goods, they also believe that halal goods have positive values and trusted safety to be used. Although it does not rule out the possibility of non-Muslim consumers who are also keen on using them, because everything which is halal is good for health.

However, the development of Halal Mart is still less known compared to other retailers that sell through supermarkets or hypermarkets, and the fact that many Muslims do not

*Corresponding author: hariadipramono@yahoo.com 
know the existence of Halal Mart's retail and its products. Therefore, this study needs to be conducted in order to determine what are the factors that can affect people's purchase intention on the products of Halal Mart.

Purchase intention is essentially derived from a process of learning and thought processes, and or an experience that forms a perception. This purchase intention creates a motivation which continues to be recorded in the minds of consumers and becomes a very strong desire that in the end when a consumer must meet his needs then he will actualize what is in his mind (Deighton, 1994). To understand and attract customers, the company must have a strong belief in the minds of consumers. Trust is a foundation in a business process. A transaction between two or more parties will occur if both sides trust each other. Belief in a business cannot come instantly but must be built from the beginning of the business' establishment (Hendrata et al, 2013).

Public interest in the retail of halal mart should be great, that one of the indicators is the amount of purchase intention of the society that can be seen from the growth of sales in the halal retail which increased from the previous year, but the fact stated otherwise. The data showed the growth of halal retail in 2017 decreased from the previous year. Even though the majority of the population in Indonesia, including in Banyumas regency, are Muslims, amounting to 1.76095 million of a total population of 1,801,477 (Data of BPS of Central Java in August 2016). Logically, the purchase intention of society in retail that sells halal products is also big, especially since Muslims are instructed to consume halal products. Therefore, religiosity factor can influence the purchase intention in halal retail which all of its products are guaranteed halal like halal mart. Therefore, the factor of religiosity is the next factor that can affect people's buying interest in the retail of halal mart. The research of Adi and Adawiyah (2018), Glock (1972) also Ateeq-ur-Rehman and M. Shahbaz Shabir (2010) suggest that religiosity is divided into six dimensions, ideological, ritualistic, intellectual, consequential, experiential. However, the researchers will only discuss religiosity through three dimensions wglockhich are considered the most important and essential, that are ideological, ritualistic, intellectual.

The gap phenomenon above is the reason for the researchers to conduct research on the purchase intention of Muslim society on halal mart retail. This study uses the research of Arshia Mukhtar and Muhammad Mohsin Butt (2012) as its main journal, which conducted research on the influence of subjective norms, attitudes, and religiosity toward purchase intention. The results show that subjective norms, attitudes, and religiosity strongly influence the purchase intention of halal products. On the other hand, a research done by Kusumawardhani et al (2016) who studied the effect of religiosity, product quality, islamic branding and value consciousness toward purchase intention. The results showed that only value consciousness that significantly influences purchase intention, while religiosity, product quality, branding Islam do not influence the purchase intention of halal products. Further research conducted by Hashim (2017) underlying the use of trust variable in this study, in which the result is that trust can also mediate the effect of the product benefits and corporate image toward purchase intention. These results indicate that variable trust can be used as a mediator.

Therefore, the researchers are interested in conducting research on the effect of religiosity toward purchase intention in Halal mart which is mediated by trust. The research novelty is the purchase intention of consumers who use Multi-Level Marketing (MLM).

\section{Formulation of the research problem}

1. Does religiosity influence the consumers' trust in Halal Mart?

a. Does ideological dimension, ritualistic dimension and intellectual dimension influence trust? 
2. Does religiosity influence the purchase intention in Halal Mart?

a. Does ideological dimension, ritualistic dimension and intellectual dimension influence on purchase intention?

3. Does trust influence on the purchase intention in Halal Mart?

4. Does trust mediate the effect of religiosity on purchase intention in Halal Mart?

\section{Objective}

The objective of this study is to investigate and analyze:

1. The effect of religiosity on consumers' trust on Halal Mart.

a. The effect of ideological dimension, ritualistic dimension and intellectual dimension on trust.

2. The effect of religiosity on buying intention in Halal Mart.

a. The effect of ideological dimension, ritualistic dimension and intellectual dimension on purchase intention.

3. The effect of trust on purchase intention in Halal Mart.

4. The mediation of trust in the effect of religiosity on purchase intention in Halal Mart.

\section{Research model}

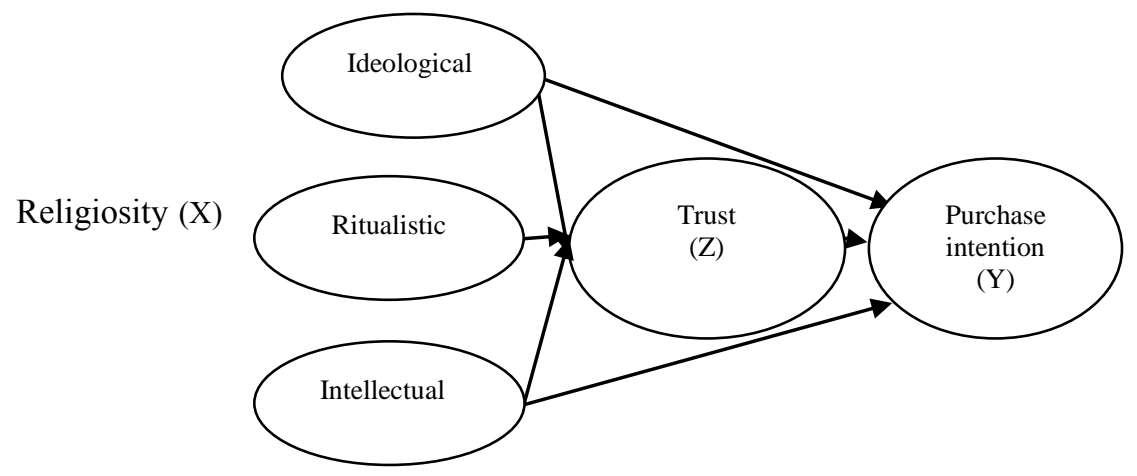

Fig. 1. Research Model

\section{Research hypothesis}

H1: Religiosity influences consumers' trust.

H1.a. (H1): ideological dimension influences trust.

H1.b. (H2): ritualistic dimension influences trust.

H1.c. (H3): intellectual dimension influences trust.

$\mathrm{H} 2$ : Religiosity influences the purchase intention in the halal mart.

H2.a. (H4): ideological dimension influences purchase intention.

H2.b. (H5): ritualistic dimension influences purchase intention.

H2.c. (H6): intellectual dimension influences purchase intention.

H7: Trust influences the purchase intention in halal mart.

H8: The trust in mediating the effect of religiosity on the purchase intention in the halal mart. 


\section{Research method}

\subsection{Objects of research}

This research was conducted in the area of Purwokerto city, precisely in Baitussalam Great Mosque, General Sudirman Mosque, Wijayakusuma Mosque, Bhayangkara Mosque, Darussalam Mosque, and Fatimatuzzahra Purwokerto Mosque.

\subsection{Population and research sample}

The population in this study are all talim assembly members of the Baitussalam Great Mosque, General Sudirman Mosque, Wijayakusuma Mosque, Bhayangkara Mosque, Darussalam Mosque, and Fatimatuzzahra Purwokerto Mosque.

According to Hair, et al. (2010) who suggested that by using Equational Structural Model (SEM), the minimum sample size is 100 . It is suggested that the sample size is $5-10$ times the parameter.

Sampling in mosque using cluster random sampling method. The cluster used was mosques in the city of Purwokerto. Based on this method, the mosques which were selected as the samples are Baitussalam Great Mosque, General Sudirman Mosque, Wijayakusuma Mosque, Bhayangkara Mosque, Darussalam Mosque, and Fatimatuzzahra Purwokerto Mosque. The next step in selecting the sample of talim assembly member using a simple random sampling method.

\subsection{Data types and sources}
a. Primary Data
In this study, primary data were directly obtained from respondents through the questionnaire on religiosity, trust, and purchase intention.
b. Secondary Data
Secondary data of this study were obtained by doing reviews of the works of literature; Fundamentals of Marketing, Marketing Management, Journal of Islamic Marketing, Journal of Marketing, Scientific Journal of Economics and Management Student, and other journals besides management journals as supporter.

\subsection{Conceptual and operational definitions}

\subsubsection{Variable of purchase interest $(Y)$}

a. Conceptual Definition: Consumer behavior in response to an object that shows a desire to make a purchase (Kotler and Keller, 2012).

b. Operational Definition: The desire of Muslim consumers to buy in the halal mart.

c. Indicators (Kotler and Keller, 2012): The urge to buy in the halal mart; The notion of halal mart; The knowledge of halal mart products; The confidence in buying in the halal mart

d. Measurement: Consumers are encouraged to buy in the halal mart; Consumers understand about halal mart; Consumers know the products in the halal mart; Consumers are confident in buying in the halal mart 


\subsubsection{Variable of trust $(Z)$}

a. Conceptual Definition: Consumers trust the reliability and integrity of a company (Kotler and Keller, 2012)

b. Operational Definition: Consumers trust in the halal mart

c. Indicators (Robbins and Judge, 2007): Integrity, correctness of the information and services; Competence, meeting consumer needs; Consistency, maintaining product value

d. Measurement: Truth of the product information; Purchase service is as expected; Meeting the needs of consumers for goods; Only selling halal and quality products

\subsubsection{Variable of religiosity $(X)$}

a. Conceptual Definition: Someone's degree in believing religious values and practice the values of his religion (Lung et al, 2008)

b. Operational Definition: Consumer's trust toward his religion including dimensions of (Glock, 1972):

c. Indicators

1) Ideology Dimension: Believes Allah; The Prophet as a role model; heaven/hell; Believes Judgment day; Allah the Helper

2) Ritual Dimension: Prayer; Reading basmalah; Reading Quran; Ramadan fast; Halal consumption; Istighfar

3) Intellectual Dimensions: Remembers Allah; Justifying the teachings of Islam; Knows about sin; Obeys religion; Stay away from the forbidden

d. Measurements

1) Ideology Dimensions: Believes Allah: Prophet Muhammad as a role model; Believes heaven and hell; Believes with the help of Allah

2) Ritual Dimensions: Pray 5 times/day; Reading Basmalah before every move; Read Quran; Ramadan fasting; Eats and drinks halal food or drink; Istighfar if guilty

3) Intellectual Dimension: Always remember Allah; Justifying the teachings of Islam; Knowledge of big and small sins; Obeys to the teachings of Islam in life; Stay away from the forbidden

\subsection{Data analysis technique}

This study uses two kinds of analysis techniques:

a. Confirmatory factor analysis in the SEM used to confirm the factors that are most dominant in a variable group.

b. Regression Weight in the SEM used to determine how much the studied variables influence each other

\section{Analysis results}

\subsection{Classic assumption test}

\subsubsection{Normality test}

In the SEM test, the data must be normal. Univariate and multivariate normality of the data used in this study were tested using AMOS. SEM analysis requires to meet the assumptions 
of normality, in which according to Ghozali (2008) normality of the data using the criteria of critical ratio (cr) skewness value equals to +2.58 at the significance level of 0.01 . The data can be concluded to have a normal distribution if the value of the critical ratio (cr) skewness value is below the absolute price of 2.58. In table 2 (appendix), it can be seen that the value of the critical ratio (cr) and skewness value of all the indicators are under the absolute price of 2.58. Based on these values, it can be concluded that the assumptions of normality of data in this study are met and can be used in the subsequent analysis phase.

\subsubsection{Outliers evaluation}

The detection of multivariate outliers was done by looking at the value of Mahalanobis Distance. The determination criterion is to compare the value of Mahalanobis Distance to the value of Chi-Square. At a significance level of $\mathrm{p}<0.01$. Chi-Square value of this study is to look at the degree of freedom equals to 50.892. Based on the analysis using a computer program of AMOS 18 on the Text Output > Observations farthest from the centroid (Mahalanobis Distance), it can be concluded that this analysis did not find multivariate outliers because the value of Mahalanobis Distance is less than X2 (50.892).

\subsubsection{Evaluation of multicollinearity and singularity}

In this research, it is known that the highest value of Mahalanobis Distance is 69.330, then the result is 2,039 . That result is below the limit of 2.5 then it can be concluded that there is no multicollinearity and singularity so that the data in this study are suitable for use.

\subsubsection{Model suitability test}

Table 1. The result of model suitability test (Goodness of Fit Test)

\begin{tabular}{cccc}
\hline Goodness - of - fit index & $\begin{array}{c}\text { The result of } \\
\text { research model }\end{array}$ & Cut of Value & Information \\
\hline Chi-Square & 556,511 & $<559,438$ & Good \\
Significant probability & 0,060 & $\geq 0,05$ & Good \\
GFI $\geq$ & 0.873 & $\geq 0,90$ & Marginal \\
AGFI & 0.850 & $\geq 0,90$ & Marginal \\
$C F I$ & 0.994 & $\geq 0,95$ & Good \\
$T L I$ & 0.993 & $\geq 0,95$ & Good \\
CMIN/DF & 1.100 & $\leq 2,0$ & Good \\
RMSEA & 0.021 & $\leq 0,08$ & Good
\end{tabular}

One of the test equipment to measure the overall fit is the likelihood ratio chi-square statistic. Chi-Square is very sensitive to the size of the sample used. The model that will be tested would be considered good or satisfactory when the value of Chi-Square is low. The smaller the chi-square, the better the model is accepted based on the probability of the cutoff value of $p>0.05$ (Ferdinand, 2011). In this study, the chi-square value obtained is equal to 436,511 and $p=0.060$, thus it can be concluded that the model in this study includes into 
a very good fit since the calculated chi-square value is greater than the chi-square table and a greater probability value of 0.05 , so that the hypothesized model fits the data.

\subsubsection{Construct validity test}

Table 2. The result of Construct Validity Test

$\begin{array}{ccc}\text { No. } & \text { Variabel (Construct) } & \text { Reliability value }(\boldsymbol{\alpha}) \\ 1 . & \text { Ideological } & 0,994 \\ 2 . & \text { Ritualistic } & 0,995 \\ 3 & \text { Intellectual } & 0,992 \\ 4 & \text { Trust } & 0,995 \\ 5 & \text { Purchase Intention } & 0,993\end{array}$

The calculated result of construct reliability as presented in the table above, it appears that the seven variables or latent constructs used in this study have I coefficient $>0.70$ or greater than the cut-off value $(>0,700)$, so we concluded that the latent constructs used in this research are really reliable.

\subsubsection{Extract variance test}

Table 3. The result of extract variance test

$\begin{array}{ccc}\text { No. } & \text { Variabel (Construct) } & \begin{array}{r}\text { The value of } \\ \text { Variance }(\boldsymbol{\alpha})\end{array} \\ \text { 1. } & \text { Intellectual } & 0,962 \\ 2 . & \text { Ritualistic } & 0,970 \\ 3 . & \text { Ideological } & 0,971 \\ 4 . & \text { Trust } & 0,980 \\ \text { 5. } & \text { Purchase Intention } & 0,972\end{array}$

The calculated result of variance extracted is listed in Table 4 above which shows that the four latent constructs used in this study have I coefficient $>0.50$ or greater than the cut-off value $(>0.500)$, so we concluded that the latent constructs used in this study are really reliable.

\subsubsection{Convergent validity test}

According to Ghozali (2008), the indicators of a latent construct must converge or share a high proportion of variants and this is what it is called as convergent validity. In the process of measuring construct validity, it can be seen from its loading factor. In cases where there is high construct validity, then a high loading value on a factor (latent constructs) indicates that they converge at one point. The first prerequisite is that the loading factor must be significant. 
Therefore, a significant loading factor may still be of low value, then the value of standardized loading estimate must be $>0.50$ and it should ideally reach a value of 0.70 . The result of convergent validity test can be seen in the table below.

Table 4. The result of Convergent Validity test

\begin{tabular}{|c|c|c|}
\hline Variable & Indicator & $\begin{array}{c}\text { Loading } \\
\text { Factor }\end{array}$ \\
\hline \multirow[t]{5}{*}{ Ideological } & $\mathrm{X} 1$ & 0,876 \\
\hline & $\mathrm{X} 2$ & 0,840 \\
\hline & $\mathrm{X} 3$ & 0,841 \\
\hline & $\mathrm{X} 4$ & 0,863 \\
\hline & $\mathrm{X} 5$ & 0,848 \\
\hline \multirow[t]{6}{*}{ Ritualistic } & X6 & 0,817 \\
\hline & $\mathrm{X} 7$ & 0,838 \\
\hline & $\mathrm{X} 8$ & 0,883 \\
\hline & X9 & 0,873 \\
\hline & $\mathrm{X} 10$ & 0,890 \\
\hline & $\mathrm{X} 11$ & 0,815 \\
\hline \multirow[t]{5}{*}{ Intellectual } & $\mathrm{X} 12$ & 0,847 \\
\hline & $\mathrm{X} 13$ & 0,857 \\
\hline & $\mathrm{X} 14$ & 0,826 \\
\hline & $\mathrm{X} 15$ & 0,845 \\
\hline & X16 & 0,799 \\
\hline \multirow[t]{4}{*}{ Trust } & $\mathrm{X} 27$ & 0,874 \\
\hline & $\mathrm{X} 28$ & 0,878 \\
\hline & $\mathrm{X} 29$ & 0,886 \\
\hline & $\mathrm{X} 30$ & 0,862 \\
\hline \multirow[t]{4}{*}{ Purchase Intention } & X31 & 0,848 \\
\hline & $\mathrm{X} 32$ & 0,867 \\
\hline & X33 & 0,898 \\
\hline & X34 & 0,815 \\
\hline
\end{tabular}


From Table 4 above, it is known that the loading factor value of all indicators are statistically significant because loading is greater than the cut-off $>0.50$. Therefore, it can be concluded that all the indicators used are valid and can be used in the analysis at the next stage.

\subsubsection{Discriminant validity test}

The discriminant validity test used to measure a construct that is different from the other constructs. A way to test the discriminant validity is to compare the value of the square root of the average variance extracted (AVE) with the correlation between the composites (constructs). The result of discriminant validity test of each variable in this study is presented in the table below.

Table 5. The result of Discriminant Validity test

\begin{tabular}{|c|c|c|c|c|c|}
\hline & Intellectual & Ritualistic & Ideological & Trust & Purchase intention \\
\hline Intellectual & $\mathbf{0 , 9 8 1}$ & & & & \\
\hline Ritualistic & 0,916 & 0,985 & & & \\
\hline Ideological & 0,916 & 0,920 & $\mathbf{0 , 9 8 5}$ & & \\
\hline Trust & 0,936 & 0,937 & 0,908 & $\mathbf{0 , 9 9 0}$ & \\
\hline Purchase intention & 0,950 & 0,938 & 0,941 & 0,958 & $\mathbf{0 , 9 8 6}$ \\
\hline
\end{tabular}

Based on Table 5 above, it is known that the AVE value of Intellectual construct is 0.983, Ritualistic is 0.985 , Ideological is 0.985 , Trust is 0.990 e and Purchase intention is 0.986. Based on these results, it can be concluded that the entire AVE values of constructs for each variable in this study are greater than the square of the correlation between the constructs which meet the requirements of good discriminant validity.

\subsubsection{Full model causality test}

The test criterion is to compare the value of $\mathrm{P}$ with a significance level used in this study which is $95 \%(0.05)$. If the value of $\mathrm{P}>0.05$, we conclude that there is no influencing relationship between the two variables. 
Table 6. The result of Full Model Causality Test: Regression Test

\begin{tabular}{cccccc}
\hline & & & C.R. & t tabel & P \\
\hline Trust & $<---$ & Ideological & 0,651 & 1,960 & 0,515 \\
Trust & $<---$ & Ritualistic & 3,388 & 1,960 & 0,000 \\
Trust & $<---$ & Intellectual & 1,999 & 1,960 & 0,046 \\
Purchase intention & $<---$ & Trust & 2,233 & 1,960 & 0,026 \\
Purchase intention & $<---$ & Intellectual & 0,213 & 1,960 & 0,832 \\
Purchase intention & $<---$ & Ritualistic & $-0,034$ & 1,960 & 0,973 \\
Purchase intention & $<---$ & Ideological & 2,132 & 1,960 & 0,033 \\
Trust & $<--$ & Religiusitas & 18,546 & 1,960 & 0,000 \\
Purchase intention & $<---$ & Religiusitas & 4,505 & 1,960 & 0,000 \\
\hline
\end{tabular}

The analysis result of mediating trust variable on the influence of religiosity which includes the dimension of Ideological, Ritualistic, Intellectual, toward purchase interest in the halal mart. Based on the results obtained by SEM analysis, results about the influence of religiosity which include the dimension of Ideological, Ritualistic, Intellectual, and trust both directly and indirectly (mediation) as well as the total effect toward the purchase intention of the standardized total, direct and indirect effects which are as follow:

Table 7. The result of Total, Direct and Indirect Effects test

\begin{tabular}{|c|c|c|c|c|c|c|c|c|}
\hline & & & & & \multicolumn{3}{|c|}{ Koefisien Jalur } & \multirow{2}{*}{ Information } \\
\hline & & & & & Total & Direct & Indirect & \\
\hline Intellect & $\rightarrow$ & Trust & & & 0,319 & 0,319 & & \\
\hline Ritual & $\rightarrow$ & Trust & & & 0,414 & 0,414 & & \\
\hline Ideologi & $\rightarrow$ & Trust & & & 0,073 & 0,073 & & \\
\hline Religius & $\rightarrow$ & Trust & & & 0,969 & 0,969 & & \\
\hline Intellect & $\rightarrow$ & Trust & $\rightarrow$ & PI & 0,130 & 0,032 & 0,097 & Not mediate \\
\hline Ritualist & $\rightarrow$ & Trust & $\rightarrow$ & PI & 0,122 & $-0,004$ & 0,126 & Not mediate \\
\hline Ideologi & $\rightarrow$ & Trust & $\rightarrow$ & PI & 0,237 & 0,215 & 0,022 & Mediate \\
\hline Religius & $\rightarrow$ & Trust & $\rightarrow$ & PI & 0,983 & 0,892 & 0,091 & Mediate \\
\hline Trust & $\rightarrow$ & Purchase intention & & & 0,306 & 0,306 & & \\
\hline
\end{tabular}




\section{Hypothesis discusion}

1. First Hypothesis (H1)

Ideological dimension has no effect on consumers' trust in the halal mart. In the future, the halal mart expected to be more concerned with the element of ideological dimension in order to build consumers' trust in the halal mart better. For example, by convincing consumers that the sold products and sales system in the halal mart is in accordance with Islamic law.

2. Second Hypothesis (H2)

Other dimensions that also strengthen the effect of religiosity toward trust positively influence and significant is ritualistic dimension. Deeds like never missed praying five times, always read Basmalah in any activities, foods, and beverages are halal, foster a desire or push to have a view or heart inclined toward things that are in accordance with the rules of Islam, also have high trust in the halal mart.

3. Third Hypothesis (H3)

Intellectual dimension included in the dimension that has a positive and significant impact on trust. Remembering Allah, believing the truth of His teaching, knowing the big or little sins, always trying to obey the teachings of Islam in all aspects of life and keep yourself from everything that is forbidden will heighten the consumers' trust on the mart more.

4. Fourth Hypothesis (H4)

Ideological respondents believe in the existence of Allah, heaven and hell, the Day of Judgment, the Prophet Muhammad as a role model and Allah is the Helper which have led to a sense that life must be lived in accordance with Islamic law, as well as using or consuming halal products also have a high intention for buying in the halal mart.

5. Fifth Hypothesis (H5)

Unlike the ritualistic dimension, this dimension does not miss a practice such as praying five times, reading Quran every day, full fasting during Ramadan, saying istighfar if making a mistake cannot influence the purchase intention in the halal mart. With this result, the halal mart will further strengthen the elements associated with the ritual dimension in the future in order to increase purchase intention of consumers. For example, by adding an easily accessible outlet so that consumers more easily and frequently come to the halal mart that will make consumers more interested and increased purchase intention.

6. Sixth Hypothesis (H6)

Similar to the ritualistic dimension, intellectual dimension also does not influence purchase intention. By remembering Allah, believing the truth of the teachings of Islam, knowing the big and little sins, always trying to obey the teachings of Islam in every aspect of life are still not able to provide a positive effect on purchase intention. This is a concern for the party of the halal mart to evoke the intellectual dimension of consumers in order to build a positive relationship with the halal mart which will further increase purchase intention. It can be done by providing evidence that the purchase of products in the halal mart is the right step both in terms of health and faith.

7. Seventh Hypothesis (H7)

From the research results, the description of consumers' trust in the halal mart is high. This suggests that consumers perceive the halal mart as a reliable seller to meet their needs for products with branded halal. This is in line with the views expressed by Kolsaker and Payne (2002) that trust is the dimension of a business relationship that 
determines the degree to which each of the parties feels they can rely on the promise offered by the other party. Therefore, trust is a foundation in a business process.

It is proved empirically that the trust influence on the purchase interest of consumers in the halal mart. This can happen because the trust was awakened by the hope that the halal mart will provide services in accordance with the needs and desires of consumers. When someone has trusted others, they believe that the expectations will be met and there will be no disappointment (Ryan, 2002).

8. Eighth Hypothesis (H8)

The values on the analysis results of all dimensions show that trust mediates the effect of religiosity on purchase intention. This means that consumers' trust strengthens the effect of religiosity on consumers' purchase intention in the halal mart.

The analysis results of mediation of trust influence on each dimension of religiosity toward consumers' purchase intention which varies between dimensions. The analysis results showed that trust mediates the effect of the dimensions of experiential, ideological, and consequential toward the consumers' purchase intention in the halal mart. However, trust does not mediate ritualistic and intellectual dimension toward the the consumers' purchase intention in the halal mart.

This shows that trust is not always able to strengthen a Muslim's religiosity to buy in the mart that clearly sell halal products. However, it can also occur due to the possibility of each individual which has a different subjective norm. The extent to which a person's religiosity affect his lives is dependent on the subjective norm in him.

\section{Conclusions and implications}

\subsection{Conclusions}

1. The dimension of ideological influences consumers' trust in the halal mart.

2. The dimension of ritualistic effect influences consumers' trust in the halal mart.

3. The dimension of intellectual influences consumers' confidence in the halal mart.

4. The dimension of ideological influence on the purchase intention of consumers in the halal mart.

5. The dimension of ritualistic does not influence the purchase intention of consumers in the halal mart.

6. The dimension of intellectual does not influence the purchase intention of consumers in the halal mart.

7. Trust influences the purchase intention of consumers in the halal mart.

8. Trust mediates the effect of religiosity on purchase intention.

\subsection{Implications}

1. Inform the halal mart that religiosity gives a positive effect to trust and the purchase intention of consumers in the halal mart and trust gives a positive effect on the purchase interest of consumers in the halal mart.

2. In addition, to give information to consumers that religiosity empirically influences consumers' trust and their purchase intentions in the halal mart, and their trust influence purchase intention in the halal mart.

\section{References}

[1] P. Hari Adi and W. R. Adawiyah, J. Islam. Mark. 9, 841 (2018) 
[2] A. Mukhtar and M. Mohsin Butt, J. Islam. Mark. 3, 108 (2012)

[3] J. Deighton, C. M. Henderson, and S. A. Neslin, J. Mark. Res. 31, 28 (1994)

[4] A. Ferdinand, Metode Penelitian Manajemen Pedoman Penelitian Untuk Penulisan Skripsi, Tesis, Dan Disertasi Ilmu Manajemen. Edisi III (AGF Books. Fakultas Ekonomika dan Bisnis Universitas Diponegoro, Semarang, 2011)

[5] I. Ghozali, Structural Equation Modelling, Edisi II (Universitas Diponegoro, Semarang, 2008)

[6] C. Y. Glock, in J. E. Faulkner (Ed.). Relig. Influ. Contemp. Soc. Readings Sociol. Relig. (C. E. Merril Publishing Company, Columbus, Ohio, 1972)

[7] Hair, J.F., Black, W.C., Babin, B.J., and R. E. Anderson, Multivariate Data Analysis. Seventh Edition (Prentice Hall, 2010)

[8] Hashim, Int. J. Econ. Commer. Manag. 5, 329 (2017)

[9] Y. K. Hendrata, T. Purbandari, and Mujilan, J. Ris. Manaj. Dan Akunt. (2013)

[10] Kolsaker and C. Payne, Mark. Intell. Plan. 20, 206 (2002)

[11] P. Kotler and G. Armstrong, Principles Of Marketing Kotler 14th Edition Pearson (2012)

[12] Kusumawardhini, S. Sarah, S. R. H. Hati, and S. Daryanti, in 3rd Int. Conf. Bus. Econ. 21 - 23 Sept. (2016)

[13] C. Lung, L. Chai, and R. Zulkufly, J. Bus. Syst. Gov. Ethics 3, 43 (2008)

[14] A. Rehman and M. Shahbaz Shabbir, J. Islam. Mark. 1, 63 (2010)

[15] S. P. Robbins and T. A. Judge, Organizational Behaviour (Pearson Education, Inc., Upper River, New Jersey, 2007)

[16] C. Bicchieri, E. Xiao, and R. Muldoon, Polit. Philos. Econ. 10, 170 (2011) 